\title{
Research on Sexist Language in EFL Literature: Towards a Non-Sexist Approach
}

\author{
CARMen PÉREZ-SABATER \\ Universitat Politècnica de València
}

Received: 26 July 2013 / Accepted: 12 August 2014

ISSN: $1697-7467$

\begin{abstract}
Centred on studies on language and gender, this article presents the results of a discourse analysis that examines the discourse practices of some of the most representative EFL textbooks published in the last decades in Spain. The analysis shows that women were subrepresented in the textbooks published in the last decades of the $20^{\text {th }}$ century. On the contrary, a very different situation occurs in the materials of the corpus calibrated to The Common European Framework of Reference for Languages since they reveal a balanced representation of sexes ${ }^{1}$, favouring, in some cases, a positive discrimination approach towards women.

Keywords: discourse analysis, EFL, gender bias, Common European Framework of Reference for Languages (CEFR).

Investigación sobre el lenguaje sexista en libros de texto de inglés como lengua extranjera: Hacia una aproximación no sexista

RESUMEN: Centrado en los estudios sobre lenguaje y género, este artículo presenta los resultados de un análisis del discurso que examina las prácticas discursivas de los libros de texto más representativos de las últimas décadas usados en las clases de inglés en España. El análisis señala que las mujeres han sido discriminadas en los libros de texto publicados en las últimas décadas del siglo XX. Por el contrario, los materiales del corpus que siguen el Marco Común Europeo de Referencia para las Lenguas muestran una situación muy diferente dado que representan a ambos sexos de forma igualitaria, favoreciendo, en algunos casos, una discriminación positiva hacia las mujeres.

Palabras clave: análisis del discurso, enseñanza de inglés como lengua extranjera, discriminación sexual, Marco Común Europeo de Referencia para las Lenguas (MCER).
\end{abstract}

\section{INTRODUCTION}

In his history of the twentieth century, the eminent historian, Eric Hobsbawm (1994), characterises the second half of the century as one marked by profound social and cultural revolutions. Hobsbawm identifies five key cultural upheavals: the death of the peasantry, the dramatic growth of higher education, the decline and fragmentation of the industrial working class and the ideological crisis of the proletariat in the passage to a new economy, based

\footnotetext{
${ }^{1}$ In this research, the terms sex and gender are used indistinctly following Williams and Best (1990).
} 
on the new technologies, the "strikingly greater part played ... by women" in the labour market (1994:338) and the development of an influential youth culture which overturned the traditional subordination of children to parents and younger to older generations.

As regards the role of women and young people in society, Hobsbawm (1994) underlines that there have been profound changes in the family and household i.e. in the structure of relations between the sexes and generations. Before the cultural revolution, the vast majority of humanity shared a number of characteristics: formal marriage with privileged sex-relations for the spouses, patriarchal values implying the superiority of husbands to wives and of parents to children, as well as of senior to junior generations.

In the second half of the $20^{\text {th }}$ century, these long-lasting arrangements began to change remarkably quickly, at least in the developed Western countries, although unevenly even within these regions. In England and Wales in 1938 there was one divorce for every fiftyeight weddings (Hobsbawm, 1994), but in the mid-1980s one for every 2.2 new weddings (UN Yearbook, 1987). In 2010, there were more than eleven divorces for every thousand married couples in England and Wales, five times as many as in 1961 (The Guardian, 2011).

As Hobsbawm argues, all five cultural revolutions have contributed to a questioning of traditional patriarchal values. Arguably, the latter two have contributed most directly. The crisis of patriarchy cannot, of course, be equated with its defeat, but it does bring into play a change of strategy, and so a change of social practices, among which we can set changes in discourse practices. The development of a youth culture in the fifties and the sixties is most obviously connected with these profound changes in discourse practices. As Hobsbawm (1994: 329-332) underlines:

Youth culture became the matrix of the cultural revolution ... Two of its characteristics are therefore relevant. It was both demotic and antinomian. The demotic style was a convenient way of rejecting the values of parental generations or, more precisely, a language in which the young could grope for ways of dealing with a world to which their seniors' rules and values no longer seemed relevant.

The impact of youth culture on discourse practices is perhaps nowhere so evident as in the commercial arts, advertising, and especially pop music. The contribution made by the incorporation of women into the labour market to the informalization of discourse may seem less obvious. It seems clear that in a traditional, patriarchal society, women talk (Coates, 1996) is restricted to the private sphere and rigorously excluded from the workplace and the more prestigious areas of discourse. It would, therefore, seem normal for the influx of women into the labour market to influence discourse practices. I do not, of course, wish to imply that this process has been effortless. There are numerous well-documented studies of gender discrimination through existing discourse practices in the workplace (see, for example, Fine (1993), Tannen (1994), Kendall and Tannen (1997), Berryman-Fink (1997), among many others). During the last decades, though, some important actions have been taken in order to get rid of biased language such as the use of guidelines and handbooks and the enforcement of the principles political correctness puts forward (see, for example, The Linguistic Society of America Guidelines for Nonsexist Usage). However, a language reform that changes sexist uses and creates neutral ones is still needed. I am, of course, aware of the limitations of a merely linguistic reform but as Andersson and Trudgill (1992: 31) argue: 
$\ldots$ in these cases (of racist and sexist language) language is a symptom, not a disease in itself. ... encouraging non-sexist language will not in itself lead to sexual equality, although drawing attention to sexist language ... can be a useful thing to do. Drawing attention to the symptoms can make people more aware of the disease and more inclined to take steps to combat it.

In this line of research, the first section of this paper seeks to explain some of the features that make language use sexist. Next, I shall make a short reference to the Common European Framework of Reference for Languages (CEFR). Section 4 includes the purpose of the study, a detailed description of the 12 EFL textbooks that form the corpus and the parameters for sexist language usage developed to monitor the visual and linguistic content in these learning materials. The next section presents the interpretation of the results of the analysis and a detailed comparison of a course published in 1995 and another calibrated to the CEFR. A discussion section and some conclusion to the study will follow. I shall finally propose some classroom activities about gender imbalance and sexist use of language.

\section{Can we say language is Sexist?}

In studies on language and gender, feminists like Frank (1989), Lledó (1992) or Spender (1998) have concluded that our languages are sexist. In their opinion, they represent or 'name' the world from a masculine viewpoint and in accordance with stereotyped beliefs about women, men and the relationship between them. In this line of thought, linguistic representation is not a neutral and transparent means of representing reality, but androcentric and, thus, there is a biased representation of the sexes in language. The bias concerns the portrayal of men as the norm and women as the appendage or as the exception in language. Linguistically speaking, males appear as non-gendered or generic subjects, while women, on the other hand, seldom do. Women are precisely defined, never as general representatives of humanity or all people, but as specifically feminine categories. As an example of how women would suffer linguistic discrimination, the two different usages of the same word can be seen in the following sentences:

He is a secretary: i.e. he works for an organization.

She is a secretary: i.e. she does typing and general office work for a person.

(Pauwels, 1998: 59)

He is a professional: i.e. a highly qualified worker.

She is a professional: i.e. a prostitute.

(Spender, 1985: 19)

According to studies such as Spender (1995) and Doyle (1998), other instances of sexist usage in the English language, which could be extended to many other languages, would be the following:

- Conventional titles and forms of address (Mrs. Smith; Dear Sir,).

- The morphological marking of many female-referring agent nouns (actress, usherette). 
- The availability of more sexually pejorative terms for women than men.

- The generic use of masculine pronouns.

- The use of the male generic 'man' to refer to the human species.

- The use of job titles ending in '-man' and considered to be 'generic' terms.

- The asymmetrical use of first and last names. Women are more often called by their first, men by their last, even when they are of equal rank (It is interesting to point out that we speak of Thackeray, but routinely speak of Jane Austin).

- Women make more use of vocabulary related to sewing and cooking, men to mechanics and sports.

- Some feminine terms are derogatory or negative, while the masculine term is often positive or non-judgemental (contrast, for example, ladies' man and man-eater).

- Many negative terms for women have no masculine counterpart, and even when counterparts exist they are often little used. Nymphomania, for example, is widely used to describe the condition of a woman who is considered sexually active and eager. The masculine 'equivalent', satyriasis, is rarely, if ever, heard (Doyle, 1998).

In Spender's (1998) opinion, language is sexist because men have had the power to determine the meanings it encodes, and these meanings embody men's perceptions of reality rather than women's. In her own words: "Males, as the dominant group, have produced language, thought, and reality. Historically it has been the structures, the categories, and the meanings which have been invented by males" (Spender, 1998: 98).

As for Cameron (1998: 11) sexism in language is not just naming the world from a male perspective but a "multifaceted phenomenon, taking different forms in different representational practices, which have their own particular histories and characteristics". To her mind, what is sexist is how certain linguistic subsystems represent gender: generic masculine pronouns, feminine suffixes, etc. Eckert and McConnell-Ginet (2013), in this concern, posit that the words we choose do matter. In their view, the use of generic masculines is not simply a linguistic convention, there are other discursive practices involved, in other words, they imply a discursive tendency to exclude "... those who belong to specially marked subcategories of the genus" (2013: 208).

López and Morant (1995), on the other hand, consider that language cannot be inherently sexist because it is an instrument to express thoughts, not an ideology. In their view, the problem is that men have power over women and this supremacy is reflected on language. According to this line of argument, we should distinguish between language structure, which simply provides the units for a code and thus cannot be sexist, and language use and pedagogical practices which, indeed, can be sexist since they reflect ideologies. For the purpose of this research, this view will be adopted throughout the article, although some considerations need to be explained. First, despite the fact that language is not an ideology, linguistic convention can be clearly influenced by it. As Eckert and McConnell-Ginet (2013: 22) put it, linguistic convention, for example, the convention when we say Mr. and Mrs. Jones mentioning men before women, has been "overtly determined by gender ideology, and in turn, supports that ideology at least implicitly", in this case, gender ideology that implies that men are more worthy and should be mentioned before women, as grammarians of the XVI century defended. Secondly, the statement that language structure cannot be 
inherently sexist needs also to be nuanced slightly since languages such as Indo-European had a distinctly sexist language structure showed in the gender system ${ }^{2}$.

On balance, these approaches to language and gender bring us to a difficult issue: if society is imbalanced "...what the relationship should be between language textbooks and society- should they represent a more progressive situation than actually exists?" (Sunderland, 2002: 2).

In this context, considering the debate about prescriptive or descriptive positions in language teaching, I have undertaken a diachronic study of the representation of women in EFL textbooks in order to see if the comparison of language learning materials published before non-sexist guidelines with the newly developed materials following the directives of the CEFR can give rise to fruitful outcomes. Further implications of this discourse analysis on language learning and gender bias will be commented upon. Overall, this article forms part of a broader ongoing line of research centred on language, power and gender (PérezSabater and Pérez-Sabater, 2013; Pérez-Sabater and Montero-Fleta, 2014).

\section{NeW CONTEXTS IN EUROPEAN LANGUAGE LEARNING}

Teaching languages in Europe has developed a profound process of standardization in the last few years due to the incorporation of The Common European Framework of Reference for Languages (CEFR) in secondary and higher education throughout European education centres. The CEFR is the result of extensive research and work on communicative objectives. Published in 2001, the purpose of the Framework is to "provide a basis for the mutual recognition of language qualifications, thus facilitating educational and occupational mobility" (CEFR, 2001: 1). The CEFR is a document which describes:

i) the competences necessary for communication;

ii) the related knowledge and skills;

iii) the situations and domains of communication.

Moreover, the Framework defines levels of proficiency which permit to measure learners' progress at each stage of learning on a life-long basis for several European languages. Consequently, progress in language learning is calibrated according to six levels of attainment, which range from $\mathrm{A} 1$ to $\mathrm{C} 2$.

The main benefits of the CEFR in language teaching could be that it "seeks to make it easier for teachers, learners, publishers and testers to communicate across languages, educational sectors and national boundaries" (North, 2004). The harmonization provided by the CEFR is seen as a necessity by European governments and educational institutions (Pérez-Sabater, 2012).

\footnotetext{
${ }^{2}$ Watkins (1998:65) posits that in Indo-European "the familiar three-gender system masculine, feminine, neuter probably at an earlier date opposed just of masculine (animate?) and neuter (inanimate?), with the feminine an original derivational rather inflectional category". This gender distinction implied that for example, in Latin, many feminine singular in *-a were originally collective plural inactive or inanimate, such as aqua (Gamkrelidze and Ivanov, 1995).
} 
These days, the Framework is gaining importance as it has been recommended in setting up the reforms in secondary and higher education systems throughout Europe, which try to make academic degree standards and quality assurance standards more comparable and compatible throughout Europe.

Along with linguistic competences, the CEFR promotes non-language-specific competences such as sociocultural knowledge and pragmatic competences. As for sociocultural knowledge, that is, the knowledge of the society and culture of the community or communities in which a language is spoken, the CEFR proposes that it merits special attention since "unlike many other aspects of knowledge it is likely to lie outside the learner's previous experience and may well be distorted by stereotypes" (CEFR, 2001: 102). The features characteristic of a society and its culture may include, among others, interpersonal relations between sexes.

That apart, in relation with language learning materials in Europe, we must mention some of the initiatives that have emerged during the last decades with the clear orientation of promoting a non-sexist approach to language teaching materials, specifically to English Language Learning and teaching materials. Among these, it would be interesting to highlight the efforts of the "Women in EFL Materials" group, an originally British movement dedicated to show men and women playing the roles traditionally associated with the other sex in learning materials and to evaluate the current materials used in class. The group's publications also centred on suggesting strategies to counteract gender imbalance (Walter, 1991; Florent et al., 1994).

\section{TeXtbook analysis}

\subsection{Purpose of the study and corpus}

The analysis of language materials and the portrayal of sexes are of long tradition in language learning research. Hartman and Judd (1978) observed that women were less visible than men in textbooks, by studying both the linguistic and the visual content of the learning materials. More than thirty years later, I have analysed the representation of women and sexist use of language in a corpus of 12 EFL textbooks used for secondary and tertiary education published in Spain by the most important companies in ELT. The main purpose of this piece of research is to explore gender imbalance in these learning materials.

Corpus analysis is used in many branches of linguistics and language learning because it makes linguistic analysis more objective since it gathers samples of a larger population (McEnery et al., 2006). In corpus based approaches, a corpus should be balanced, representative and the sampling should be proportional to its weight in the target population so as to consider it as representative, that is to say, "a sample is assumed to be representative if what we find for the sample also holds for the general population" (McEnery et al., 2006:19). In my study, the population is the books published in Spain for learning English and the sample is two of the most widespread books from each decade of the second half of the $20^{\text {th }}$ century. From each book or sampling unit I chose half of the units in order to examine these samples exhaustively. Specifically, I chose the odd units of each book as a random criterion for corpus selection since the manual analysis carried out required some sort of selection to make it possible. Therefore, this research project explored half of the units of these books, the odd units, which amounts to 921 pages of written text and all the visual images, an abundant representative sample of the population studied. 
As for the period of publication of the books, it is necessary to clarify some points. As mentioned in the introduction to this article, the second half of the $20^{\text {th }}$ century suffered deep social and cultural revolutions which changed society and, in turn, may have affected learning materials. Framed in these revolutions, it could be of scholarly interest to observe whether the discourse practices of representative textbooks from each decade, starting in the 1950 s and ending in the 2000s, have reflected these social changes. Furthermore, the comparison of coursebooks issued before the introduction of non-sexist guidelines with materials developed more recently, which should follow the recommendation for balanced and non-stereotyped presentation of males and females, can give rise to interesting conclusions.

A final consideration in this corpus preparation was that, to obtain a homogeneous corpus of analysis, all the books are intermediate or B1 according to the CEFR. This selection implies that even though every book is analysed individually, the results can be compared and, at the same time, computed totally as part of a single corpus. The decision to study intermediate textbooks was based on the fact that they are related to a learning stage at which the linguistic input is set in richer and less superficial contexts than those of beginners and not as complex or specific as those of higher levels. Also, with respect to the intermediate coursebooks published in the last decade, I would like to point out that the last two textbooks of the list were chosen because they are currently being used by the author and follow the guidelines of the CEFR. Consequently, these two criteria, the publishing dates and the level of the books, were the variables to form a representative sample of the publications designed for intermediate English language courses in Spain.

The following is the list of books examined:

1. Haycraft, J. (1956). Getting on in English. BBC English. Madrid: Alhambra.

2. Hicks, D. (1957). Calling All Beginners. London, Madrid BBC: Alhambra.

3. Mangold, W. (1965). Modern English: A New Intermediate Course. Madrid: Mangold.

4. C.E.L.A (1968). Look, Listen and Speak II. Madrid: S.M., Mangold and Enosa.

5. O'Neill, R., Kingsbury, R. and Yeadon, T. (1971). Kernel Lessons. Intermediate. London: Longman.

6. Fowler, W. S., Pidcock, J. and Rycroft, R. (1979). Incentive English. III. Middlesex: Nelson.

7. Hartley, B. (1982). Streamline English. Destinations: An intensive course for intermediate students. Oxford University Press.

8. Taylor, J., Ahem, P. and Shepherd, J.(1986). Ways to Reading. London: Macmillan.

9. Hutchinson, T. (1993). Hotline. Intermediate. Oxford: Oxford University Press.

10. Lawley, J., O’Neil, H. and Bradbury, T (1995). Fountain. 4. London: Thomas Nelson and Sons.

11. Cotton, D., Favley, D. and Kent, S. (2008). Language Leader Intermediate. Harlow: Pearson.

12. Wheeldon, S. and Campbell, C. (2008). Get it Right 2. Oxford: Oxford University Press.

These coursebooks have been analysed following the parameters defined in the next sub-section. However, to avoid the profusion of tables and numbers, only some examples are provided below from the study of the first nine books. The results will finish with a detailed comparison of the last coursebooks cited. 


\subsection{Method of study}

A systematic quantitative content analysis was carried out following the studies of Hartman and Judd (1978), Spender (1995), and Doyle (1998), among others. Sexist language usage in language teaching materials was studied under these parameters:

- gender visibility in drawings and photographs;

- female and male subjects/objects in examples and texts, in other words, how many women or men are the subjects or objects of sentences;

- jobs both sexes do;

- conventional titles and forms of address employed;

- pronoun usage.

\section{RESULTS AND THEIR INTERPRETATION}

In the first coursebook published, Getting on in English (1956), there isn't any visual image of women alone in drawings and photographs, females are always represented with men; for example, in one image, a woman is buying curtains in a shop, the man is the shop assistant. Interestingly, this volume includes translation into English, which also exemplifies a markedly androcentric approach: "El rico hombre de negocios le habría dado también una pulsera si ella hubiera sido más amable con él" (the rich businessman would have given her a bracelet if she had been nicer to him). Later, these learning materials seem to display less stereotyped images of men and women. In Hotline (1993), for example, there are some visual images of women represented as housewives wearing an apron but also as astronauts; men, for the first time in the corpus, are shown in tasks less typically associated with the male stereotype like carrying bags from the market or drying the dishes.

As for female and male subjects/objects in examples and texts, men dominate most of the sentences and dialogues. For instance, in Incentive English III (1979) we find only one conversation between women and this conversation is about a man. Moreover, sexist use of language is common in sentences of the type: "Julia often gets to work late" and "he came on time but she did not" (Kernel Lessons, 1971). In Hotline, in turn, there is a balanced number of men and women in examples, conversations or texts.

In professional domains, in the 1950s women work only as queens or housewives whereas men are businessmen, politicians, and taxi drivers. Remarkably significant is the fact that in 1993 women began to be co-pilots, astronauts, and headmistresses.

Regarding the use of conventional titles, within the earliest books of the corpus, there is a deeply marked distinction between married and unmarried women by addressing subjects as Miss Smith or Mrs. Smith, which generally follows a Mr. Smith. While a few instances of women's names without a title are found in the 1970s and 1980s, men are always mentioned with one, in most cases the form of address $\mathrm{Mr}$ or sometimes $\mathrm{Dr}$. It is worth observing that no use of the title $M s$ is found in the first nine textbooks in spite of the fact that its use had already been introduced into the lexicon of address forms in the late sixties (Eckert and McConnell-Ginet, 2013).

Diachronically, the use of pronouns has significantly changed. In the early language books, there is a discursive tendency to use the masculine as the generic for sex-indefinite 
meanings like in the following sentence from Ways to Reading (1986) "... to permit the busy reader to choose which articles he will read, and which he will pass over". In the 1980s, some occurrences of his or her are seen sporadically (Streamline English, 1982). Later, for example in Hotline, we find his/her in all cases.

On balance, the purpose of the analysis has been completely fulfilled. As previously expected, the diachronic study has ascertained that offensive stereotyped images and inappropriate language use have been often employed in these learning materials. Not surprisingly, the results of the study present a clear misrepresentation of women in the first EFL textbooks studied, as for visual images and linguistic content, although important changes in the portrayal of sexes can be observed comparatively. Undoubtedly, there has been a clear effort to avoid gender bias step by step.

\subsection{Detailed comparison of two coursebooks}

The next step of the study will see whether the impact of the actions taken to get rid of biased language has a significant effect on the last materials of the corpus. To this end, the following tables display a detailed comparison of the data obtained from Fountain 4 (1995), one of the books issued just after the movement "Women in EFL Materials" set its guidelines on how to write materials, and Language Leader Intermediate, one of the two textbooks calibrated to the CEFR in the corpus.

The comparison of results is organised in tables, which give general information about the textbook and the description of the results for each parameter studied.

Table 1. Textbook description

\begin{tabular}{|l|l|}
\hline & \multicolumn{1}{|c|}{ Bibliographic Features } \\
\hline Textbook 1 & $\begin{array}{l}\text { Title: Fountain 4 } \\
\text { Authors: Jim Lawley, Helen O'Neill, Tom Bradbury } \\
\text { Publisher: Longman } \\
\text { Year: 1995 }\end{array}$ \\
\hline Textbook 2 & $\begin{array}{l}\text { Title: Language Leader Intermediate } \\
\text { Authors: David Cotton, David Falvey and Simon Kent } \\
\text { Publisher: Pearson Longman } \\
\text { Year: 2008 }\end{array}$ \\
\hline Textbook 1 & $\begin{array}{l}\text { Pages analysed: 42 Corpus } \\
\text { Units analysed: 14 }\end{array}$ \\
\hline Textbook 2 & $\begin{array}{l}\text { Pages analysed: } 84 \\
\text { Units analysed: } 6\end{array}$ \\
\hline
\end{tabular}




\subsubsection{Visual content}

As Table 2 shows below, in 1995 women are clearly outnumbered by men visually. Besides the traditional clichéd image of housewives in early textbooks, women are seen as secretaries, shop assistants, stewardesses, co-pilots, and teachers.

Example 1. Image of Fountain 4 where a woman is the co-pilot ${ }^{3}$

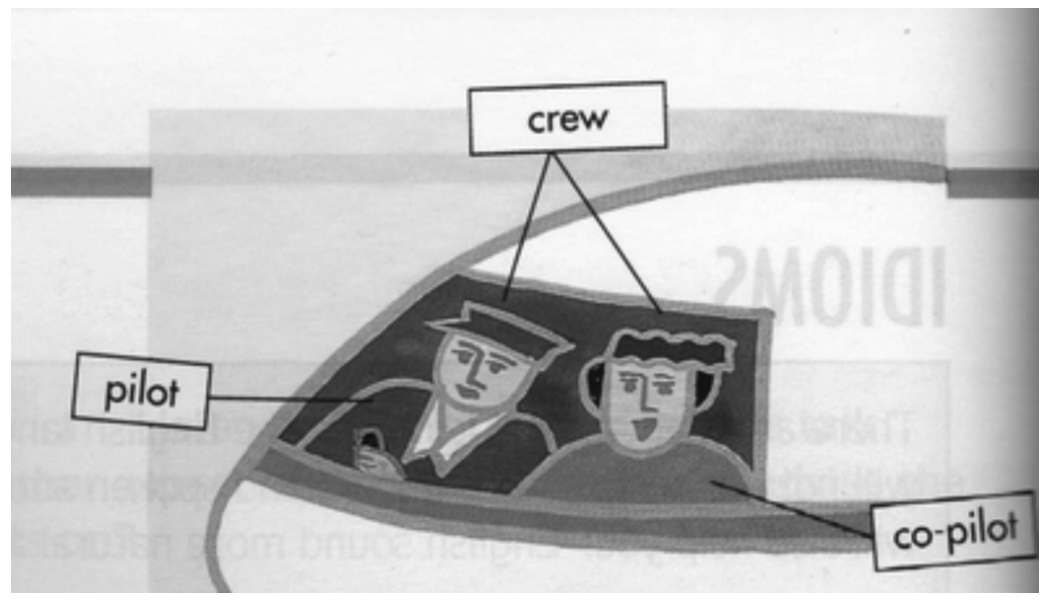

In 2008, however, women are shown in roles typically supposed to be the domain of the other sex like principals, engineers, and journalists, as in Example 2:

Example 2. Image of a woman in the introductory reading exercise of the lesson about engineering from Language Leader Intermediate

\section{$2 \mathrm{a}$ Look at the text. Where do you think it comes from? Who is it aimed at?}

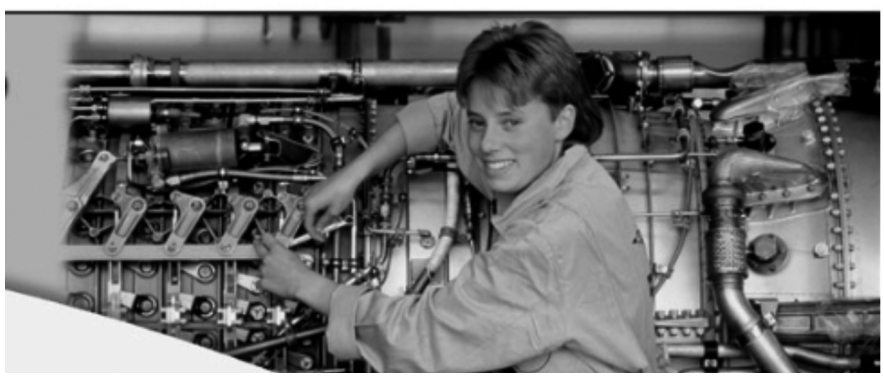

\footnotetext{
${ }^{3}$ The author has written permission to publish these images for research purposes.
} 
Regarding men's visibility, in 1995, they are usually portrayed as being and working outside their houses; for example, they are managers and skilled workers. In 2008, men are seen designing and building.

Table 2. Quantitative results of the analysis of visual images (drawings and photographs)

\begin{tabular}{|c|c|c|c|c|}
\hline $\begin{array}{c}\text { Year of } \\
\text { publication }\end{array}$ & Women & Men & Women \& Men & Non personal \\
\hline 1995 & $7.3 \%$ & $39.1 \%$ & $26.3 \%$ & $27.3 \%$ \\
\hline 2008 & $25 \%$ & $28 \%$ & $30 \%$ & $17 \%$ \\
\hline
\end{tabular}

\subsubsection{Linguistic content}

While in 1995 more reading passages were written by men and about men, in 2008 the two genders are portrayed much more fairly and equally. Stories about women are now as frequent as the ones with a male character and some reading activities promote a debate about gender issues, for example, the role of women engineers or single-sex schools.

The titles used in 1995 refer to Mrs Parker, Mrs Salmon or The Mackie family. Conversely, in Language Leader Intermediate, we usually find people with a name and no title such as Marie Laforet; titles are seen only sparingly when a teacher is called Mr. Jones and a customer Mrs Daley.

As for the presentation of pronouns and generic pronouns and terms, in 1995 the masculine pronoun he usually comes first and him/her is employed for generalization. In 2008, we frequently see him or her when the gender is unknown. Likewise, generic terms use the masculine in the book published in 1995 such as cave men or man's best friend, while in 2008 people and everyone are the most commonly used subjects for generalization, generic terms of the type salesperson or working person are preferred throughout the book. In Language Leader Intermediate, only some instances of generic he and his are found to refer to a supplier and when the editor of a newspaper is addressed as Dear Sir.

Table 3. Percentage of female and male subjects/objects in examples

\begin{tabular}{|c|c|c|}
\hline Year of publication & Female & Male \\
\hline 1995 & $45 \%$ & $55 \%$ \\
\hline 2008 & $55 \%$ & $45 \%$ \\
\hline
\end{tabular}

Table 4. Men versus women mentioned in texts.

\begin{tabular}{|c|c|c|c|c|}
\hline $\begin{array}{c}\text { Year of } \\
\text { publication }\end{array}$ & Women & Men & Women \& Men & Non personal \\
\hline 1995 & $13 \%$ & $41 \%$ & $15 \%$ & $31 \%$ \\
\hline 2008 & $27 \%$ & $26 \%$ & $35 \%$ & $12 \%$ \\
\hline
\end{tabular}




\section{Discussion AND IMPLications OF THE STUDY}

Comparatively, the results of the analysis show a significant quantitative change that has occurred over the span of a few years. While no attempt can be made to generalise findings from one case study, this undoubtedly demonstrates that authors and publishers have made a great effort to combat sexism in language teaching in the last decades and adapt their publications to the directives of, for example, The LSA Guidelines for Nonsexist Usage (1986). Indeed, these efforts may have an impact on society and, as Andersson and Trudgill (1992) indicated, may, in turn, make people more inclined to combat sexism. Interestingly, the research undertaken has also revealed that the materials we use are politically correct. It could even be suggested that, in some cases, these textbooks follow a positive discrimination approach towards women, often promoting gender debates in the classroom. As an example, the unit about engineering in Language Leader Intermediate has a female engineer as the subject of both the reading and the listening exercise, the principal of the university is a woman, and one of the greatest explorers chosen is a woman as well.

Nevertheless, despite the positive results obtained in this study that show the profound changes in the family and household posited by Hobsbawm (1994), other recent studies on gender bias and EFL textbooks suggest that there is still a pervasive manifestation of sexist usage in other corpora (e.g. Ansari and Babaii, 2003). Thus, in clear contrast to our findings, some researchers claim that little has changed over the past decades since their textbooks studied continue to show an androcentric orientation, presenting material and knowledge from a masculine-generic perspective with females largely invisible in the text or treated as secondary (e.g. Ansari and Babaii, 2003; Otlowski, 2003).

On balance, the results of my analysis, which indicate the important step ahead undertaken by European learning institutions, authors and publisher to avoid sexism in learning materials may have some important implications from a cultural point of view, since textbooks have a criterion of authority. In this way, Cortazzi and Jin (1999) argue that EFL textbooks have important functions on several levels. Textbooks can work as a "teacher, a map, a resource, a trainer, an authority, a de-skiller and as ideology" (Cortazzi and Jin, 1999: 199-200). As Olson (1989) claims, the criterion of authority also entails that textbooks have authority and are regarded as the legitimate version of the knowledge valid in society. The possibility of disagreeing with what textbooks express is, therefore, nearly inexistent for a student. In fact, coursebooks, as printed sources, make words impersonal, objective, and are beyond criticism. Furthermore, the opportunity to criticise and dissent is smaller when the distance between the discourse writer and the receiver is bigger. As a result, the attitude of students towards what textbooks affirm is usually one of respect and firm belief.

When we talk about EFL textbooks, the authority over the students is even greater, since learners do not frequently have arguments to disagree or to ground their opinion about either linguistic or extralinguistic contents. This is the reason why non-sexist approaches to language learning may, in the end, have a positive impact on society.

\section{Some ClasRrom ACTIVITIES AND GENDER BIAS}

Finally, although the results drawn from this corpus comfirm the absence of gender imbalance in the new materials for language learning examined, some activities may still be 
needed to reinforce this non-sexist approach or to mitigate gender bias in language learning materials in other contexts (see, for example, Ansari and Babaii, 2003). In my view, ludic activities that deal with prescriptivist approaches to language learning could be a good strategy to initiate a debate and enhance discussion in English. One of the ingredients of classroom games is to have fun while changing classroom routines. Thus, it is much more challenging and entertaining to make students aware of the importance of using appropriate language and avoiding gender stereotypes by means of fun activities. This could be the right context in which games can be adopted in the classroom, a difficult issue for teachers according to Hsu and Wang (2010). A dynamic and attractive approach through games can be the most adequate tool to tackle inequality in language and society while learning English. These activities can make this topic more attractive to intermediate learners.

In class, after playing with games and riddles, a discussion is usually held to make students aware of how often women's invisibility and subrepresentation are found in language and current society.

The activities proposed have been adapted from resource books for language teachers and from teaching guidelines.

a) Riddles (Adapted from MEC (1988). Guía didáctica para una orientación no sexista.)

Task 1. Riddles

Aim: to show how the hiding of women in language produces the masculinization of language.

Time: $10 \mathrm{~min}$. each

Participants: the whole class.

Level: Intermediate, B1.

Try to solve the following riddles:

- Smith had a brother. Smith's brother died. However, the man who died never had a brother. How is that?

- A father and his son were in a car when, suddenly, the father lost control of the vehicle and they crashed into a telephone pole. The father died immediately. His son was seriously injured and taken to hospital where he had to be operated on. When the doctors on call appeared in the operating theatre, a voice was heard that said: "I cannot operate on this boy: he's my son".

Procedure: after presenting the riddles to the class, observe how the students react and how long it takes them to guess the correct answer. The fact that addressing people may be another way of categorising them may be the centre of a follow-up debate. A debate on the second riddle may also give rise to interesting opinions on the professions traditionally associated with each sex. 
c) Story games (Adapted from Wright, A. et al. (1983). Games for Language Learning. Cambridge: Cambridge University Press.)

\section{Task 2. Story games}

Aim: to see how women and men are regarded by learners.

Time: $15 \mathrm{~min}$.

Participants: the whole class.

Level: Intermediate, B1.

Procedure: class work. The teacher begins the story with the first half of a sentence. Then, the students finish it. For instance:

Teacher: I saw a man working ...

Student 1: ... in an office.

Teacher: The man was...

Student 2: ... very tall and strong.

Teacher: Next to him, there was a woman...

Student 3: ...who was his secretary.

As answers are being given, the teacher writes down the answers on the blackboard and the results are commented on with the whole class. A discussion about the gender relations implied by this sort of dialogue finishes the activity.

c) Role inversion (Adapted from Agüera, I. (1999:173). La mujer de papel. Madrid: CCS.)

\section{Task 3. Role inversion}

Aim: "to put oneself in the other's place" referring to the roles traditionally given to women and men at home.

Time: $30 \mathrm{~min}$.

Participants: the whole class and volunteers.

Level: Intermediate, B1.

Procedure:

Step 1. Teacher and students plan and prepare the performance of a scene from the daily life of a family (mother coming back home after a working day, time to make dinner while the family is at home, the cleaning-up day, etc.)

Step 2. Students volunteer to take part in the performance, but boys play the part traditionally associated with women and girls that with men. In this way, we encourage students to put themselves in the place of others, to think and feel like the opposite sex and explain and analyse the situations personally experienced.

Step 3. An in-class discussion focuses on the discriminatory situations that participants have experienced during the performance, which they probably experience every day in their homes. 
d) The odd person out, this is an up-dated version of the traditional game the odd man out.

Task 4. The odd person out

Aim: make students aware of how sexist language (generic-masculine terms, suffixes in -ess or titles such as Miss) is still used in the English language.

Time: $15 \mathrm{~min}$.

Participants: the whole class.

Level: Intermediate, B1.

Procedure:

Step 1. Students have to spot the incorrect word from a series of words. For example:

1- Actress - Waiter-Actor-Driver-Doctor

2- Ms- Mr-Dr-Miss- Ph. D

3- Police officer-Chairman-Sales person-Fire fighter

Step 2. After finding the word, they have to explain why the term is not suitable and give an alternative neutral word.

\section{Bibliography}

Agüera, I. (1999). La mujer de papel. Madrid: CCS.

Andersson, L. and Trudgill, P. (1992). Bad Language. Harmmonsworth: Penguin.

Ansari, H. and Babaii, E. (2003). "Subliminal sexism in current ESL/EFL textbooks", in Asian EFL Journal, 5, 1, article 1, available from: http://www.asian-efl-journal.com/march03. sub1.php, accessed 12 November, 2013.

Berryman-Fink, C. (1997). "Gender issues: Management style, mobility, and harassment", in P. Y. Byers (ed.), Organizational communication: Theory and Behavior. Boston, MA: Allyn and Bacon, 259-283.

Cameron, D. (ed.)(1998). The Feminist Critique of Language. London and New York: Routledge. Coates, J. (1996). Women Talk. Oxford: Blackwell.

Cortazzi, M. and Jin, L. (1999). "Cultural mirrors: Materials and methods in the EFL classroom", in E. Hinkel (ed.), Culture in Second Language Teaching and Learning. Cambridge: CUP, 196-219.

Council of Europe (2001). Common European Framework of Reference for Languages, available from http://www.coe.int/t/dg4/linguistic/cadre_en.asp, accessed 10 October, 2013.

Doyle, M. (1998). "Introduction to the A-Z of non-sexist language", in D. Cameron (ed.), The Feminist Critique of Language. London and New York: Routledge, 149-154.

Eckert, P. and McConnell-Ginet, S. (2013). Language and Gender. Cambridge: Cambridge University Press.

Fine, M. (1993). "New voices in organizational communication: A feminist commentary and critique", in S. Perlmetter Bowen and N. Wyatt (eds.), Transforming Visions: Feminist critiques in communication studies. Cresskill, NJ: Hampton Press, 125-166. 
Florent, J., Fuller, K., Pugsley, J., Walter, C. and Young, A. (1994). "Case Study 1: On balance: Guidelines for the representation of women and men in English language teaching materials. Exploring gender: Questions and implications for English language education”, in F. Frank and P. A. Treichler (eds.), Language, Gender, and Professional Writing: Theoretical Approaches and Guidelines for Nonsexist Usage. New York: MLA, 112-120.

Frank, F. (1989). "Language planning, language reform, and language change: A review of guidelines for nonsexist usage", in F. Frank and P. A. Treichler (eds.), 105-133.

Gamkrelidze, T. V. and Ivanov, V. V. (1995). Indo-European and the Indo-Europeans: A Reconstruction and Historical Analysis of a Proto-Language and Proto-Culture. Part I: The Text. Part II: Bibliography, Indexes (Vol. 80). Berlin: Walter de Gruyter.

Hartman, P. L. and Judd, E. L. (1978). "Sexism and TESOL materials", in Tesol Quarterly, 12, 4: 308-393.

Hobsbawn, E. (1994). Ages of Extremes: The Short Twentieth Century 1914-1991. St Ives: Abacus.

Hsu, Y. and Wang, S. (2010). "Using gaming literacies to cultivate new literacies", in Simulation \& Gaming, 41, 3: 400-417.

Kendall, S. and Tannen, D. (1997). "Gender and language in workplaces", in R. Wodak (ed.), 81-105.

Lawley, J., O’Neil, H. and Bradbury, T. (1995). Fountain. 4. Harlow: Longman.

Lledó, E. (1992). El sexisme i l'androcentrisme en la llengua: anàlisi i propostes de canvi. Barcelona: I.C.E.

López, A. and Morant, R. (1995). Gramática femenina. Madrid: Cátedra.

McEnery, T., Xiao, R. and Tono, Y. (2006). Corpus-Based Language Studies. Oxford: Routledge.

MEC (1988). Guía didáctica para una orientación no sexista, available from: http://www.educacionenvalores.org/IMG/pdf/Guia_educacion_no_sexista.pdf, accessed 9 September, 2013.

North, B. (2004). "Europe's framework promotes language discussion, not directives". Guardian Weekly, 15 April, available from: http://www.guardian.co.uk/education/2004/apr/15/tefl6, accessed 12 September, 2013.

Olson, D. R. (1989). "On the language and authority of textbooks", in S. De Castell, A. Luke and C. Luke (eds.) Language Authority and Criticism: Readings on the School Textbook. London and New York: Palmer Press, 233-43.

Otlowski, M. (2003). "Ethnic diversity and gender bias in EFL textbooks", in Asian EFL Journal, 5, 2, article 3, available from http://www.asian-efl-journal.com/june_2003_mo.php, accessed 17, March, 2014.

Pauwels, A. (1998). Women Changing Language. London and New York: Longman.

Pérez-Sabater, C. (2012). "A pioneer study on online learning environments following the Common European Framework of Reference for Languages", in Procedia-Social and Behavioral Sciences, 46, 1948-1955.

Pérez-Sabater, C. and Montero-Fleta, B. (2014). "Pragmatic competence and social power awareness: The case of written and spoken discourse in non-native English environments", in International Journal of English Studies, 14, 2.

Pérez-Sabater, C. and Perez-Sabater, M. L. (2013). "Breaking gender stereotypes in technology education: Developing strategies in the English classroom", in English for Specific Purposes World, 38, 14, available from http://www.esp-world.info/Articles_38/Abstracts/ Perez-Sabater_Breaking_gender_stereotypes.htm, accessed 16 March, 2014.

Spender, D. (1980). Man Made Language. London and New York: Pandora.

Spender, D. (1998). "Extracts from Man Made Language", in D. Cameron (ed.), 93-99. 
Sunderland, J. (2002). "New Dimensions in the Study of Language Education and Language Gender", available from: www.ling.lancs.ac.uk/groups/crile/working papers.htm, accessed 3 April, 2014.

Tannen, D. (1994). Talking From 9-5: Women and Men at Work. New York: Avon.

The Guardian (2011). "Divorce rates data, 1858 to now: Why are divorces going up?", available from: http://www.guardian.co.uk/news/datablog/2010/jan/28/divorce-rates-marriage-ons, accessed 7 November, 2011.

The Linguistic Society of America Guidelines for non-sexist Usage. (1986). LSA Bulletin, December, available from http://www.linguisticsociety.org/resource/lsa-guidelines-nonsexist-usage, accessed 2 April, 2014.

Walter, C. (1991). "On balance: Guidelines for the representation of women and men in English language teaching materials", in Women in EFL materials, available from https://oxford. academia.edu/CatherineWalter, accessed 10 April, 2014.

Watkins, C. (1998). "The Proto-Indo European: comparison and reconstruction" in A. Giacalone Ramat and P. Ramat (eds.) The Indo-European Languages. London: Routledge, 25-73.

Williams, J. and Best, D. L. (1990). Measuring sex Stereotypes: A multination Study. Newbury Park, CA: Sage Publications.

Wodak, R. (1997). Gender and Discourse. London: Sage.

Wright, A., Betteridge, D. and Buckby, M. (1983). Games for Language Learning. Cambridge: CUP. 